\title{
SZAKTUDOMÁNY KONTRA PEDAGÓGIA
}

\author{
BUdA ANDRÁS \\ a Debreceni Egyetem Neveléstudományok Intézetének \\ egyetemi adjunktusa \\ buda@delfin.unideb.hu
}

Hogy pedagógusnak születni kell vagy tanulható mesterség, régi vitája a társadalomnak. Mindkét tábor védi valónak vélt igazát, de csak ritkán sikerül meggyőzni a vitapartnert. A szakemberek természetesen egyetértenek abban, hogy vannak olyan ismeretek, fogások, módszerek melyek taníthatók, melyek ismertében felkészülte(bbe)n állhat ki a pályakezdő tanítványai elé. Általában egyetértés van abban is, hogy egyaránt szükség van szaktudományos, pedagógiai-pszichológiai és módszertani felkészítésre. A szakmabeliek ezek arányán, sorrendjén vitatkoznak, és ez volt az a kérdéskör, mely a Tanárképzők Szövetségének V. Akadémiáján talán leginkább megosztotta a megjelenteket.

Hatvani László professzor bevezető előadásában egyértelmüen a szaktudományos felkészítés elsődlegessége mellett tette le a voksot. Javaslatai között megfogalmazta például azon elképzelését, hogy csak olyan intézményben folyhasson pedagógusképzés, ahol színvonalas kutatómunka folyik. Bevallom, nem feltétlenül látok a kettő között összefüggést. Egyrészt úgy gondolom, hogy ha átvizsgálnánk napjaink közoktatásban felhasználható tankönyveit, akkor elvétve találnánk olyat, melyben az elmúlt évtizedek szaktudományos kutatásainak eredményei megjelennek. (Sőt, ha az elemzést kizárólag a természettudományos tárgyakra korlátoznánk, minden bizonnyal jelentősen nyújthatnánk az időintervallumon. Talán csak a Plútóval kapcsolatos változás az egyedüli kivétel.) A tankönyvek azonban természetesen változtak, de legföképpen azért, mert a nemzetközi és hazai kutatások (pl. PISAmérések és a kompetencia vizsgálatok) bebizonyították, hogy pedagógiai, módszertani, szemléletbeli változásra van szükség.

A szaktudományos kutatások kiemelt szerepe a pedagógusképzés szempontjából azért is kérdéses, mert az előadó maga jelentette ki, hogy a tanárjelölteknek mást kell tanítani, nem pedig kevesebbet. Ha pedig ezt elfogadjuk, akkor aligha képzelhető el, hogy a legfrissebb szaktudományos eredményekkel ne a diszciplináris képzésben résztvevőket ismertessük meg! A kiváló kutatási potenciál és a pedagógusképzés kapcsolata tehát ebből az irányból is megkérdőjelezhető. Mindazonáltal még az is kérdéses, hogy a kiváló kutatási eredmények együtt járnak-e azok átadásának képességével? Ha ugyanis végiggondoljuk tanulói pályafutásunkat, akkor valószínüleg fel tudunk idézni olyan tanárokat, akik bizonyítottan magas szintü 
ismeretekkel rendelkeztek, ennek ellenére nem tudták azt megfelelően átadni. Számos vitacsoport, továbbképzés tapasztalata alapján állítható, hogy ezen példák többsége a felsőoktatásból származik. Érdemes lenne megvizsgálni, hogy ennek aze az oka, hogy diákként még jobban tiszteljük tanárainkat, hallgatóként pedig már kritikusabbak vagyunk, vagy éppen az egyre gyarapodó ismeretek, tapasztalatok állnak a háttérben? Vajon milyen szerepe van e tanárképben annak, hogy a felsőoktatásban oktatók egy részének nincs tanári végzettsége? Mi is indokolja tehát az intézményekben zajló kutatás és a pedagógusképzés összekapcsolását?

A vitaindító előadásban elhangzott az is, hogy a pedagógiai-pszichológiai tárgyak a Bologna-rendszerben plusz 22 kreditet kaptak, és ez szintén hozzájárul a tanárképzés válságához. Ez az állítás - véleményem szerint - szintén több szempontból vitatható. Egyrészt már korábban is voltak olyan képzési programok (pl. a mérnöktanár-képzés területén), melyekhez képest a mostani 50 kredit nem jelent 22 kreditnyi többletet. Egy ilyen növekedés egyébiránt $\mathrm{kb}$. hét százaléknyi eltérést jelent a $300(180+120)$ kredithez viszonyítva. Az eltérés tehát olyan csekély, hogy a problémák egészen biztosan nem (csak) innen erednek. Ha egyáltalán léteznek problémák a képzési programokkal kapcsolatban! Az új típusú képzési programok sikere vagy sikertelensége ugyanis még nem bizonyítható, hiszen a végzettek (már ahol vannak egyáltalán!) még nem töltöttek el éveket a pedagóguspályán. Amíg ilyen eredmények, tapasztalatok nem állnak rendelkezésünkre, addig lehet éppen érdekeknek, elképzeléseknek megfelelő jóslatokban bocsátkozni, de ilyen vélelmekre nem szabad fontos döntéseket alapozni!

Tagadhatatlan ugyanakkor, hogy a korábbinál jóval kevesebben jelentkeznek pedagógusnak. Ez azonban egyáltalán nem meglepő, hiszen ebböl a szempontból a társadalom hasonlít a vita során felemlegetett példaszemélyhez, akinek ha elég sokáig ismételnek valamit, akkor a végén elfogadja, sőt sajátjának tekinti az ötletet. Valóban sikerült addig ismételgetni a „sok a pedagógus” kijelentést, míg a társadalom hozzászokott, magáévá tette a gondolatot. Így aztán a felelősségteljesen gondolkodó szülők megpróbálják lebeszélni gyermeküket a munkanélküliséget előrevetítő diplomaszerzésről, a diákok érdeklődése csökken (esetleg pontosan szüleik példáját látva), a képzésben résztvevők pedig megpróbálják csökkenteni (nem egy esetben minimalizálni) a befektetendő energia mennyiségét. Nem növelik a jelentkezők számát a médiumok tanárverésekről, iskolai atrocitásokról szóló híradásai sem, hiszen a legtöbben nyugodt, konfliktusmentes légkörben szeretnének majd dolgozni, a fizikai erőszakot megpróbálják elkerülni. Mivel azonban a legtöbb embernek nem jut eszébe, hogy ezek a híradások nem a hétköznapi történéseket mutatják be, hanem kiragadott, extrém példákkal próbálják növelni az olvasottságot, nézettséget, a hamis kép meg tud telepedni a gondolatok között.

A Bologna-rendszer ismeretlensége, újdonsága is szerepet játszik a jelentkezők alacsony számában. Jó néhány tanulói kérdés még a felsőoktatásban dolgozókat is zavarba hozza, éppen ezért nem csoda, hogy a szülök vagy a középiskolai tanárok 
sok esetben nem tudnak információkat, tanácsokat adni, a régi bevált „útvonalak” többsége napjainkban már nem járható. Nem könnyíti meg a jelentkezők helyzetét az sem, hogy nagyon sok felsőoktatási intézményben folyik tanárképzés, a korábbi nagy múltú helyszínek mellett számos új intézményben is megjelent ez a képzési forma. A közöttük történő választás azonban nem a képzési programok eltéréseinek figyelembevételével történik, ezt csak nagyon ritkán nézi meg valaki! A hírnévnek, a különböző rangsorokban elfoglalt helyezésnek, a megközelíthetöségnek, a kollégiumi ellátottságnak, a hallgatói rendezvényeknek nagyságrendekkel nagyobb szerepe van a választásban, mint annak, hogy kettő- vagy négykredites tárgyakat kell majd zömében teljesíteni. Az intézményi bőség azonban véleményem szerint csak átmeneti, gazdasági okokból a választék hamarosan szükebbé válik, hiszen nem lehet 2-3 fös képzéseket hosszú távon életben tartani.

Mindezek mellett a kétlépcsős rendszer hangsúlyosabbá tett egy korábban is létező problémát, ami nem más, mint a nyelvtudás kérdése. Diplomát már évek óta csak nyelvvizsga (nyelvvizsgák) birtokában lehet szerezni. Mivel minden évben több ezer olyan hallgató van, aki nem tesz eleget ennek az elöírásnak, ezért sokan csak később, olykor évek múlva vehetik át oklevelüket. A probléma az alapképzésben résztvevőket is érinti, közülük is minden bizonnyal leginkább azokat, akik az alapszak mellé egy minor képzésbe is bekapcsolódtak, nekik ugyanis kétféle elvárás rendszernek kell megfelelniük. Ha ez annyira leköti az energiájukat, hogy a nyelvi követelményeket nem tudják teljesíteni a három év alatt, akkor nem kapnak alapdiplomát, következöleg nem is tudnak tanári mesterképzésre jelentkezni.

Hatvani professzor előadásában jelentős problémaforrásként említette a tanár szak szakfelelőseinek hiányzó szakmai ismereteit. Teljesen egyetértek, amennyiben ilyen előfordul, ezt a - remélhetőleg csak kényszer szülte - helyzetet meg kellene szüntetni! Legalább ilyen fontos azonban az is, hogy a szakfelelős ne csak szakmai ismeretekkel, hanem tanári végzettséggel is rendelkezzen, mindkét területre szükség van! Sőt! Az lenne az ideális, ha ezen túlmenően lenne néhány éves közoktatásban szerzett tanítási gyakorlata is. A felsőoktatásban szerzett tapasztalatok ugyanis szintén hasznosak, de kevéssé hasonlítanak egy átlagos általános vagy középiskolában történtekhez. Teljesen más problémákkal kell szembenézni ezekben az intézményekben, más a tanulók igényszintje, motivációs bázisa stb. Könnyü belátni, hogy az a szakfelelős tud legszínvonalasabb munkát végezni, aki mindhárom területen otthonosan mozog, egy vagy két terület ismerete önmagában nem elég.

Jó pedagógusnak is csak az tekinthető, aki nemcsak magas szintü szaktudományos ismeretekkel rendelkezik, hanem képes azok magas szintű átadására is. Mindkét összetevőre szükség van, bármelyik hiánya sérülést okoz. A pedagógiailag, módszertanilag felkészült, de hiányos ismeretekkel bíró tanár nyilvánvalóan nem tudja majd megtanítani az adott tantárgyat, nem fogja tudni felfedezni, gondozni a területen tehetséges gyermekeket. Az, aki kiváló szaktudományos felkészültséggel 
bír, de pedagógiailag, módszertanilag felkészületlen, az viszont nemcsak az adott tárgy tanulásától tudja elvenni a diákok kedvét, hanem akár magától az iskolától, a tudás elsajátítástól, amellyel az „élethosszig tartó tanulás“ korában egy életre hátrányos helyzetbe hozhatja tanítványait. Bár utóbbit jóval súlyosabb problémának érezzük, nem lenne szabad megengedni, hogy bármelyik is bekövetkezzék! 